\title{
Application Analysis of Buying and Selling Game to Grow the Language Development and Attitude of Entrepreneurs on Child Age 5-6 Years in Paud RA Al-Mahir
}

\author{
Rasti Purnamasari ${ }^{1}$, Aman Simare-mare ${ }^{2}$, Sri Minda Murni ${ }^{3}$ \\ ${ }^{1}$ Postgraduate Student in Universitas Negeri Medan, Indonesia \\ ${ }^{2}$ Lecturer in Universitas Negeri Medan, Indonesia \\ ${ }^{3}$ Lecturer in Universitas Negeri Medan, Indonesia \\ rastipurnamasari2017@gmail.com
}

\begin{abstract}
This study aims: (1) to analyze the design of buying and selling games in Paud (early childhood education programs) on language development. (2) Knowing the selling game design process to foster entrepreneurial attitudes in Paud. (3) Realizing the reason for buying and selling games can foster the development of language and entrepreneurial attitudes. This type of research is a descriptive qualitative research that collects data directly at the source. Data analysis according to Miles and Huberman, namely: (1) data reduction, (2) data presentation, (3) inference and vertification. The results obtained from this study prove that the game of buying and selling can foster language development and entrepreneurial attitudes carried out on 3 children, namely 2 boys and one child is a girl. This research was conducted at Paud RA Al-Mahir Deliserdang.
\end{abstract}

Keywords: buy and sell games; language development; and entrepreneurship attitudes

\section{Introduction}

Education is something that must be possessed by humans, because education can elevate the lives of a nation. Bearing in mind that according to the sound of the Law on the goals of the Indonesian nation's education, which reads "National education functions to develop capabilities and shape the character and civilization of the nation and dignity in order to educate the nation, aiming at developing the potential of students to become human beings who believe, and devote to God The Almighty, having noble, healthy, knowledgeable, capable, creative, independent, and being a democratic and responsible citizen ". This Law is listed in Law No. 20 of 2003 (Wiyani, 2013: 7). The above statement regarding Indonesia's educational goals in shaping the character of learners, so as to form a generation of characters and innovative in life in the future.

Realizing this reality requires strategies and techniques that can be instilled from an early age. Early childhood education is a place to stimulate children for the development and growth of children at an early age in accordance with the sound of the Education Act. Primary school education, especially in Early Childhood Education (Paud) must educate and pay attention to the development and also the growth of early childhood to ward off existing phenomena. This reality is also as stated in the Republic of Indonesia's Presidential Regulation No. 60 of 2013 which explains that the development of holistic-integrated early age is an effort to develop early childhood which is carried out to meet the essential needs of diverse and interrelated children simultaneously, systematically, and with integrity.

Learning in Paud should be in accordance with the characteristics of children by playing, which is a market game that can improve the development of language and entrepreneurial spirit so that in the future it can overcome unemployment in Indonesia.

The world of children is a world of play that will not be far from the games, therefore early childhood education does not run away from the game. Play has meaning that is very 
meaningful for early childhood. Many games that can be played by young children one of which is a game of buying and selling.

The buying and selling game originates from Semarang district which is classified as a traditional game in the area Sujarno, et al (2013: 133). The steps of the game are: (1) preparation (2) rules (3) implementation. This buying and selling game is a role playing game (Role Playing) because the buying and selling game plays the seller and buyer. Role playing is learning designed to get more specific learning goals.

Role playing is considered as one of the best methods to help improve children's cognitive, social, and emotional competence (Blatner, 1995). Defined as "mock games between children where they temporarily act part of others using mock actions and speech" (Harris, 2000, p. 30), role play begins with the teacher introducing the problem, selecting the player, set the stage, prepare observers, present the setting, and finally discuss and evaluate the game with the whole class (Shaftel \& Shaftel, 1967). Previous research has shown that role play enhances children's language learning (Grant \& Mistry, 2010; Liu \& Ding, 2009), communication skills (Veraksa, 2011), and understanding of the attitudes of certain fields of study, such as science, mathematics, and history (Cakici \& Bayir, 2012; Deaton \& Cook, 2012; Williams, 2010; Yonamine, 2010) as the cognitive domain. Furthermore, role playing promotes interpersonal problem solving skills, self-awareness, understanding other people's feelings, expressing their own feelings, being empathetic towards others, and controlling their emotions (Kitson, 1997; Rogers \& Evans, 2006; Tyce, 2002; Wood \& Attfield, 1996) as social and emotional competence. Carried with real-life situations into the classroom, children are given the opportunity to enter and examine situations and take part in sequences of events, thus gaining an understanding of the realities they might face outside the classroom (Vygotsky, 1978). Children can represent and act out their ideas and feelings in a safe and lively environment through the experiences of others, which in turn helps them develop empathy (Tyce, 2002; Weinert \& Kluwe, 1987).

Role Playing definitions can be concluded that teaching children to play a game that is in accordance with the child's experience of something incident. This teaching can provide tangible results to a learning because children are directly involved in doing events or events, so learning that is intended can be achieved with optimal results. The game played in this teaching is about buying and selling games made by children aged 5-6 years, which is expected from the buying and selling game can foster the development of language and entrepreneurial attitudes.

The definition of buying and selling games according to the theory of Role Play buying and selling games are games that are carried out by two or more people who have miniature buying and selling which in the game has rules, can be played by boys or girls, and can foster language development and attitudes entrepreneurship.

The development of children's language is influenced by the nature of this gene in accordance with the opinion of Naom Chomsky called the natives view. J. Piaget said that language is acquired when maturity occurs and cognitive abilities develop which are called cognitive views. Behaviorist views emphasize the pattern of "nurturing" and view learning as a result of stimuli, responses, and assistance that occur in the environment according to Skinner. his interactional view is guided by socio-cultural interactions in the development of children's language knowledge. The basic premise of Vygotsky is in the language mining influenced by the society in which a person lives. The fourth theoretical view according to (Otto, 2015: 30). The following is a summary table of the theoretical views of language development: 


\begin{tabular}{|c|c|c|c|c|}
\hline \multicolumn{5}{|c|}{ Summary of Theoretical Views of Language Acquisition } \\
\hline \multicolumn{5}{|c|}{ Focus Theory parenting Focus Aspects of Theoretical Knowledge } \\
\hline Nativism & Nature & Syntax & Chomsky & \\
\hline $\begin{array}{l}\text { development } \\
\text { cognitive }\end{array}$ & Nature & $\begin{array}{l}\text { Semantics } \\
\text { Morphemic }\end{array}$ & Piaget & \\
\hline $\begin{array}{l}\text { Behaviorism } \\
\text { Semantics } \\
\text { Morphemic }\end{array}$ & Parenting & Syntax & Skinner & \\
\hline Interactions & arenting & Pragmatics & Vygotsky & \\
\hline \multicolumn{5}{|c|}{ Aspects of knowledge of spoken language } \\
\hline \multicolumn{5}{|c|}{ Language Aspects $\quad$ Oral Language } \\
\hline Phonetic & Sound sy & system base & nemes & \\
\hline Semantics & $\begin{array}{l}\text { Use of sp } \\
\text { and inton }\end{array}$ & language alo & body language, facial & expressions, \\
\hline Syntax & Arrangen & f phrases and & es or grammar & \\
\hline Morphemic & Infection & ording in the & ciation of languages & \\
\hline Pragmatics & $\begin{array}{l}\text { The use } \\
\text { includir }\end{array}$ & $\begin{array}{l}\text { ferent langua } \\
\text { aspects of lar }\end{array}$ & $\begin{array}{l}\text { variety of face to face } \\
\text { nowledge }\end{array}$ & nteractions, \\
\hline
\end{tabular}

(Otto, 2015: 24)

The conclusion of a child's language development is the ability to express feelings, ideas, and intentions of the will of the heart that the child wants to communicate to others, so that people who hear him understand about what is communicated or conveyed. Indicators of language development are: (1) language sounds, (2) use of language with body and facial expressions, (3) language intonation used by children, (4) sentence structure used by children adopted from the theories of Chomsky, Piaget, Skinner, Vygotsky and Bruner.

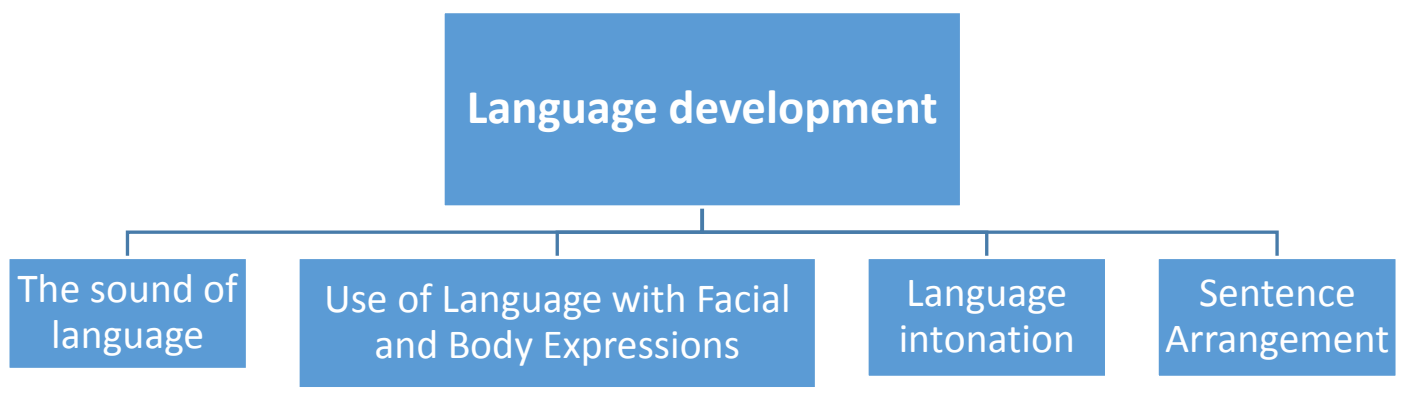

Figure 1. Schema of language development

The game of buying and selling in its implementation there are negotiation activities between sellers and buyers, so that the seller unwittingly performs an entrepreneurial attitude. Entrepreneurship in children aged 5-8 according to (Cristiantil, 2015: 9) also said that between the ages of 5 to 8 years old is the age at which children develop basic skills and have an entrepreneurial mindset that will then form the basis of children's skills for life and capable of solving every problem. His opinion said that children between the ages of 5 to 8 years are the age where children develop basic skills and have an entrepreneurial mindset which will then form the basis of the child's skills for life and be able to solve every problem. Other opinions 
such as (El Khuluqu, 2016: 12) say Entrepreneur education for early childhood is a part of efforts to cultivate a culture of entrepreneurial and the value of entrepreneurship from an early age [12] Values of entrepreneurial are dare-to-try attitude, setting the goal, having selfexpectation, strong, self-confidence, having self initiative, responsible, learning from feedback, having a good relationship with the people who can help, willing to seek advice from the experts, to implement the task systematically. His opinion said entrepreneurship education for young children is part of an effort to foster entrepreneurial culture and entrepreneurial values from an early age. [12] Entrepreneurial values are the attitude of courage to try, set goals, have self-hope, be strong, have confidence, have own initiative, responsible, learn from feedback, have a good relationship with people who can help, are willing to seek advice from experts, to carry out tasks systematically. His opinion said entrepreneurship education for young children is part of an effort to foster entrepreneurial culture and entrepreneurial values from an early age. [12] Entrepreneurial values are the attitude of courage to try, set goals, have self-hope, be strong, have confidence, have own initiative, responsible, learn from feedback, have a good relationship with people who can help, are willing to seek advice from experts, to carry out tasks systematically.

The formation of entrepreneurial attitudes should be the task of parents and teachers in schools. The role of parents is to introduce entrepreneurship by inviting children directly to familiarize themselves with completing homework with responsibility and confidence. The teacher's job is to insert school learning with learning that can support entrepreneurial attitudes, such as in Paud by playing buying and selling games.

There are several things that children will develop through the game of buying and selling, through this game the child's ability to negotiate develops. Together these abilities build confidence in children in exploiting language. This statement according to (Jufri \& Wiraman, 2014: 146). These aspects contained in the game of buying and selling have benefits in the formation of children who are tough in life.

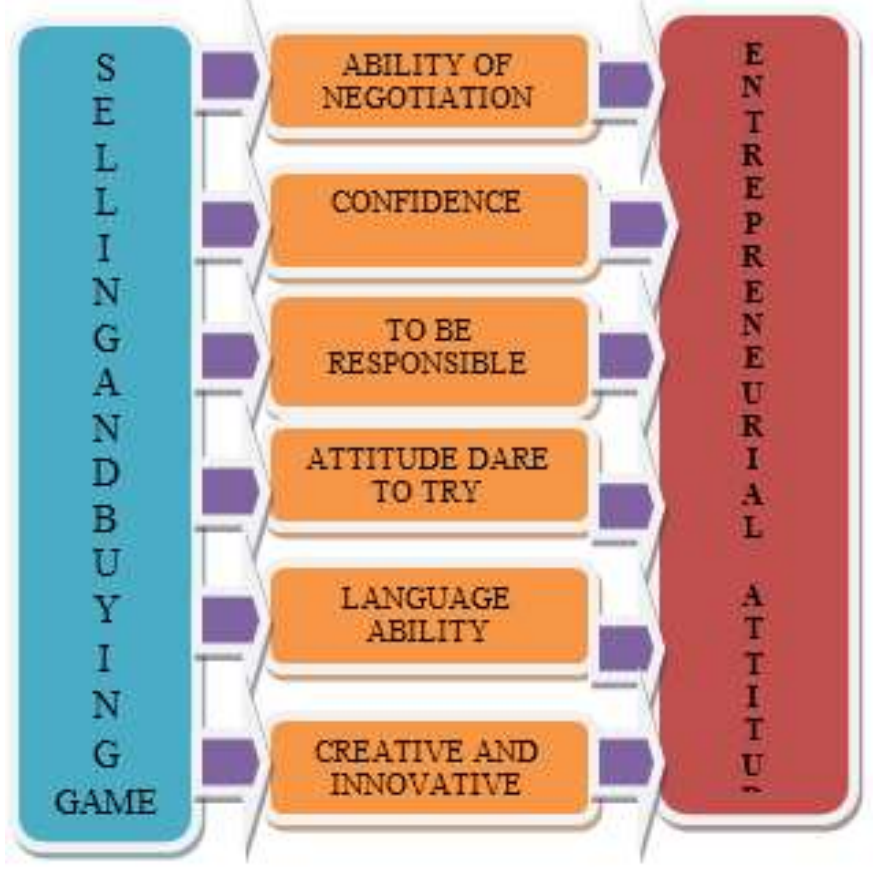

Figure 2. Formation of Entrepreneurship Attitudes in Early Childhood 
The conclusion of the entrepreneurial attitude is a business of negotiating the sale and purchase of goods, which includes language skills, confidence, responsibility, an attitude of courage to try, so that it becomes creative and innovative. The indicators of entrepreneurial attitudes are: (1) being able to negotiate buying and selling, (2) responsible, (3) courage to try, (4) language skills, (5) being creative and innovative.

\section{Research Method}

This study uses a qualitative descriptive design. Explain that the results of the study are presented to illustrate the quality. The source of data in this study is in the form of a game of buying and selling. The aim is to obtain data to foster the development of language and entrepreneurial attitudes in Paud RA Al-Mahir within 3 weeks with 3 students required by researchers to use data collection techniques. The source of the data comes from observations, interviews and documentation conducted intensively and carefully to obtain data that is consistent with the research objectives. The result of the data that has been found is recorded in the form of notes. data collection researchers set the instrument is the researchers themselves. The data analysis technique used in this study is data analysis which is carried out together with the process of data collection with the flow of stages according to Miles and Huberman (in Widiasworo, 2018: 157) as follows: (1) Data reduction, (2) Presentation of data, (3) Conclusions and Vertifications. The researcher analyzes the data that has been collected to find the meaning contained in it in accordance with the purpose of the study.

\section{Result and Discussion}

The results of the research obtained from observations made obtain data. The data includes the design of buying and selling games carried out at Paud RA Al-Mahir School which results in language development and fostering entrepreneurial attitudes in children aged 5-6 years which coincides with children who are in class B in the 2018-2019 school year. The buying and selling games are included in the learning curriculum in the learning sub-themes. The theme of buying and selling games there are 3 weeks.

Learning and selling games carried out in Paud RA AL-Mahir was designed by the teacher with the guidance of the principal. The game learning design is written in RPPM which is then detailed in making RPPH. Making RPPH in accordance with the standard competence of students at the age of 5-6 years. Writing RPPH game buying and selling in accordance with Role Play theory because it takes the form of dialogue or sociodrama conversation.

The design steps of the game include; (1) preparation and rules, (2) game implementation. The game preparation activity is the teacher arranging a dialogue plan that will be used by students. The rules of the game the teacher plays the game by setting merchandise, prices of merchandise, location of the game and players as sellers or buyers. The teacher implementation activities give the game to students to play the game of buying and selling.

Students play the game according to the dialogue in RPPH. The results of the buying and selling game in the first week are still said to be not good, because the language used by students is not in accordance with the teacher's RPPH dialogue, such as sound language, language structure, expressions and language intonation does not match the sentence designed, such as the language "buy what? "Answered" buy this ". The first week of the game was not 
yet seen as an entrepreneurial attitude because children who were selling were still shy about doing it.

The second week the children did better than last week because the sounds, language structure, facial expressions and intonation gradually improved. This event was marked by a more perfect language arrangement, such as: "who wants to buy fruits with lots of vitamins and benefits". Friends as buyers offer a predetermined price like: "can be less in price". This incident is a better language level, but the childishness attitude of the child has not yet been seen.

The last week of buying and selling games performed by the three children is better because they sell snacks for children. This event is seen as bargaining between a seller and a buyer. The seller's son offered with the language: "Who buys fresh ice gets the ball, let's buy sir?". The buyer answers with "I bought ice because I got the ball, I like ice and I also like the ball". This negation event indicates that the design of buying and selling games can be carried out well, that is supported by interviews with teachers who say "the practice of buying and selling games continuously can improve language development and entrepreneurial attitudes in children".

Table 1. Research results Starting 13 May 29, 2019

\begin{tabular}{|c|c|c|c|c|c|c|}
\hline \multirow{2}{*}{ Date } & \multicolumn{3}{|c|}{$\begin{array}{c}\text { anguage } \\
\text { Development }\end{array}$} & \multicolumn{3}{c|}{$\begin{array}{c}\text { Entrepreneurial } \\
\text { Attitude }\end{array}$} \\
\cline { 2 - 8 } & X & Y & N & X & Y & N \\
\hline 13 & C & C & C & C & - & - \\
\hline 14 & C & C & C & - & C & - \\
\hline 15 & C & C & C & - & - & C \\
\hline 16 & B & C & C & C & - & - \\
\hline 20 & B & B & C & C & - & - \\
\hline 21 & B & B & B & C & - & - \\
\hline 22 & B & B & B & - & - & C \\
\hline 23 & B & B & B & C & - & - \\
\hline 27 & SB & B & B & B & - & - \\
\hline 28 & SB & SB & B & - & B & - \\
\hline 29 & SB & SB & SB & - & - & B \\
\hline
\end{tabular}

\section{Conclusion}

The design of buying and selling games in accordance with Play Role theory in the form of socio drama can be declared successful in fostering the development of language and entrepreneurial attitudes. Game of buying and selling that is done as a condition of buying and selling children when buying snacks for children. The game does not run away from the child's life so the child knows the steps of the game more quickly.

\section{Suggestion}

Based on the findings that have been outlined in the conclusions of the results of the analysis of the application of buying and selling games, the following suggestions are proposed as follows: 
Budapest International Research and Critics in Linguistics and Education (BirLE) Journal

Volume 2, No 4, November 2019, Page: 525-532

e-ISSN: 2655-1470 (Online), p-ISSN: 2655-2647 (Print)

www.bircu-journal.com/index.php/birle

emails: birle.journal@gmail.com

birle.journal.qa@gmail.com

1. Research analysis of the application of buying and selling games is expected to support teachers in efforts to develop language and entrepreneurial attitudes in Paud learning

2. Considering that learning in Paud does not have the theme of buying and selling games, it is hoped that it can add the theme of buying and selling games as learning in Paud so that the horizons of children are increased.

3. The game trading theme is expected to be used as a reference to other traditional games

\section{References}

Antawati, Ilma, D. 2012. Membangun Sikap Kewirausahaan Pada Anak Usia Dini Dengan Permainan Tradisional Jual beli. Jurnal Ilmu Ekonomi \& Bisnis, Volome XVIII, Nomor 1. p 21-34.

Bungin, Burhan. 2003. Analisis Data Penelitian Kualitatif. Jakarta: Raja Grafindo Persada.

Contiu, C,L, et.al. 2012. Hofstede's Cultural Dimensions And Student's Ability to development Entrepreneurial Spiritt Wces 2012 www.sciencedirect.com

Christiantil, Dkk. 2015. Development of Entrepreneurship Learning Model for Early Childhood. Asia Pacific Journal of Multidisciplinary Research, Vol. 3, No. 3

Darmiasih, N,I \& Marhaeni, N, I. 2014. Penggunaan Metode Bermain Permainan Tradisional Dalam Upaya Meningkatkan Kemampuan Berbahasa dan Sosial Emosional anak Kelompok B Tk Sebaya Sari. Vol.4. e-journal Program Pascasarjana Universitas Pendidikan Ganesha Progran Pendidikan Dasar.

Daryanto, 2012. Pendidikan kewirausahaan. Yogyakarta: Gava Media

Dewi, Rosmala, 2018. Berbagai Masalah Anak Taman Kanak-Kanak. Medan: Departemen Pendidikan Nasional Diktorat Jenderal Pendidikan Tenaga Kependidikan dan Kebudayaan.

Elfiandi, 2016. Bermain dan permainan Bagi Anak Usia Dini. Vol.VIINo.1

Furio, D, 2013. Evaluation of learning Outcomes Using An Educational IPhone Game vs.Traditional Game.SciVerse ScienceDirect.

Hamalik, Oemar. 2008. Dasar-dasar Pengembangan Kurikulum. Bandung : PR Remaja Rosda Homeyer, E, L \& Morisson, O,M. 2008. Play Therapy Practice, Issues, and Trends. America Juornal Of Play.

Hoff, E, 2005. Languege development. America : The United States Of America

Jarvis, Matt, 2000. Theoritical Approches In Psychology. London: Rouledge

Jufri, M \& Wirawan, H, 2014. Interenalisasi Sikap Kewirausahaan Pada Anak.Jakarta: Kencana.

Jufri, M \& Wirawan, H, 2018. Internalizing The Spirit Of Enterpreneurship In Early Childhood Education through Traditional Games. (online) https://doi.org/10.1108/ET-11-20160176

Khuluqo, et.al. 2016. Early Childhood Entrepreneurship Education : A Brief Description Of An Ideal Entrepreneurship Learning For Middle Childhood. Proceedings The 2nd International Multidisciplinary Conference 2016 November 15th , 2016.

Kridalaksana, 2005. Pesona Bahasa Langkah Awal Memahami Linguistik. Jakarta: Gramedia.

Mahsun, M, S, 2005. Metode Penelitian Bahasa, Tahapan Strategis, dan Tekniknya. Jakarta: grafindo Persada

Mulyani, Novi, 2018. Perkembangan Dasar Anak Usia Dini. Yogyakarta: Gava

Murni, Minda, S, 2013. Kesantunan Linguistik. Medan: Unimed Press 
Murti, S,A,H. 2016. Permainan Jual beli Sebagai Media Untuk Mengembangkan Kompetensi Interpersonal Anak. Jurnal Psikologi Ulayat Vol.3. NO.2. Hlm 99-108

Otto, Beverly, 2015. Language Deveploment In Early Children Third (Terjemah). Jakarta: Prenada Media

Prasetyo, Anang. 2001. Metode Role Playing Untuk Menigkatkan Hasil belajar siswa Kelas II SLTPN 3 Driyono Gresik. Bulletin Pelangi pendidikan .Edisi IV Tahun II

Rachmawati \& Kurniadi, 2012. Strategi Pengembangan Krativitas Pada anak Usia Taman kanak-Kanak. Jakarta: Kencana Premedia

Santrock, W, J, 2008. Psikologi Pendidikan. Jakarta: Kencana

Sugiyono, 2017. Metode penelitian Pendidikan. Pendekatan Kuantitatif, Kualitatif dan R\&D. Bandung: Alfa Beta.

Suhada, Idad, 2016. Psikologi Perkembangan anak Usia Dini (Raudhatul Athfal). Bandung: Remaja Rosda Karya

Sujarno, et.al, 2013. Pemanfaatan Permainan Tradisional dalam Pembentukan Karakter Anak. Yogyakarta: Kementerian Pendidikan dan Kebudayaan

Sun, M,C \& Wu, C,H,F. 2015 . To choose or not? That is the question of memberships Fuzzy statistical analysis as a new analytical approach in child language research. (Online), http://dx.doi.org/10.1108/17465660910943757

Sunarto \& Hartono, 2008. Perkembangan Peserta Didik. Jakarta: Rineka Cipta

Susanto, Ahmad 2017. Pendidikan Anak Usia Dini ( Konsep dan Teori). Jakarta: bumi Aksara Syarif, Kemali, 2017. Perkembangan Peserta Didik. Medan: Unimed Press

Ulya, H \& Istiandaru, A. 2016. Permainan Jual beli Dalam Pembelajaran Matematika Materi Aritmatika Sosial Untuk Menumbuhkan Karakter Kewirausahaan. Seminar Nasional Pendidikan Matematika Ahmad Dahlan

Utami, R. 2013. Penerapan Permainan Jual beli dalam Pembelajaran Matematika Materi Pokok Aritmatika sosial. Vol.1No.2.115-199

Wee, SJ . 2013. Young Children Role Playing For Enhancing Personal Intelligent Multiple Intelligences Theory. Korea .Vol 4.NO.1

Weisberg, S,D. 2013. Play, Language Developmentd, and The Role of Adult Support. American Juornal of Play. Vol.6 NO. 1

Widiasworo, 2008. Mahir Penelitian Modern. Yogyakarta: Araska

Wiyani, 2013. Bina Karakter Anak Usia Dini. Panduan orang tua dan guru dalam membentuk kemandirian anak dan disiplin anak usia dini. Yogyakarta: AR-Ruzz Media

Yus, Anita. 2015. Penilaian Perkembangan Belajar Anak Taman Kanak-Kanak. Jakarta: Kencana. 